\title{
Language games vs. the game of translation
}

\author{
Oleksandr Rebrii ${ }^{1 *}$, Olha Pieshkova $^{1}$ \\ ${ }^{1}$ Mykola Lukash Translation Studies Department, V.N. Karazin Kharkiv National University, \\ Kharkiv, Ukraine
}

\begin{abstract}
The article focuses on experimental researching the strategies, methods and means of reproducing nominative language game in popular scientific discourse. We proceed from the understanding of language games by Ludwig Wittgenstein and Johan Huizinga according to which its varieties include both acts of nomination and translation. The research is based on the neological quasi-terms whose main function is not to give names to objects but to induce expressive coloring (terminological connotation) in the context. With the help of algorithmic modeling, we formulated potential strategies for ascribing meanings to English quasiterms and reproducing them in Ukrainian, and afterwards we designed and conducted the retrospective experiment aimed at verifying the above strategies. The experiment involved 34 semi-professional subjects who translated text fragments and submitted their reports concerning the reproduction of the control units (quasi-terms). The analysis of the experiment not only confirmed the validity of the modeled strategies but also allowed to describe the translators' decisions in terms of the game theory. In particular, by attempting to coin the equivalent for a nonequivalent quasi-term following the source model and word-formation elements, the translator accepts the author's rules; while by employing his/her own model and/or word-formation elements the translator offers his/her own set of rules. In either case, the reproduction of a quasi-term in its lexicalized form can be seen as the translator's victory, while omitting it in the target text is a clear sign of defeat. Descriptive translation takes a somewhat intermediate position: on the one hand, it allows to convey the meaning of the source unit, but on the other hand, it leads to the loss of the source unit's lexicalized form and concomitant terminological connotation.
\end{abstract}

\section{Introduction}

Studying the works on language games, we came to the same conclusion as the one formulated earlier by Eduard Mishkurov who claimed that linguists predominantly concentrate their attention on those manifestations of language games that "reflect the excessive use of 'humoristic' linguistic means with the conscious violation of 'linguistic norms' aimed at disrupting automatic perception of the content" and thus they "impoverish the wide-ranging meaning of language games implied by Ludwig Wittgenstein and limit themselves to describing comic and laughable discourse fragments" [1, p.8].

\footnotetext{
* Corresponding author: rebrii1967@gmail.com
} 
Indeed, this approach to comprehending language games is in conflict with our views as to linguistic and stylistic formalization of scientific discourse (Ukrainian more than English). Traditionally, scientific narration is associated with "providing new information in a strict, logically arranged and objective form" which "stems from the informative function of scientific speech and its aspiration to make a communicative impact on the recipient's mind rather than feelings" [2, p.15]. At the same time, some investigations in the field of psychology of scientific creativity prove that "thinking and its linguistic expression cannot be devoid of evaluation, imagination, intuition and expression even on the highest level of abstraction" [3, p.24], which, we believe, opens the door to the scientific discourse for all those means of linguistic expressiveness that are typically united under the umbrella term of 'language games'. In this respect, we appreciate the position by Marina Alekseeva who points at the inhomogeneous nature of scientific discourse and distinguishes within it what she calls "the humanitarian style of narration" characterized by a number of features: "These features include a larger degree of brightness, colorfulness, emotiveness, expressiveness. These features are stipulated by figurativeness of thinking, human ability to convey thoughts not only logically, but also poetically" [2, p. 16]. This observation is even more justified in respect to the so called popular scientific discourse oriented to a more extensive audience whose interest can be detained not only by scientific facts themselves but also by a more accessible form of their presentation together with a variety of expressive means.

When Wittgenstein introduced the concept of language games into linguistic paradigm and terminology, he understood it in a very broad philosophical sense embracing "the whole process of using words" [4, p.5]. This approach is labeled as activity-oriented and dynamic: "Here the term 'language-game' is meant to bring into prominence the fact that the speaking of language is part of an activity, or of a form of life" [ibid., p.11]. Meanwhile, Wittgenstein did not avoid mentioning some specific forms of language games among which our attention is drawn to the phenomenon regularly defined by linguists as 'nomination': "And there is also a language-game of inventing a name for something, and hence of saying, 'This is ... .' and then using the new name" [ibid., p.13].

Later on, the idea of treating nomination as a variety of language games was picked up and further developed by another prominent scholar Johan Huizinga who in his magnum opus "Homo Ludens" stated the following: "Take language, for instance - that first and supreme instrument which man shapes in order to communicate, to teach, to command. Language allows him to distinguish, to establish, to state things; in short, to name them and by naming them to raise them into the domain of the spirit. In the making of speech and language the spirit is continually 'sparking' between matter and mind, as it were, playing with this wondrous nominative faculty" $[5, \mathrm{p} .4]$. Taking this lead, we would like to define the aim of this research as experimental investigation of strategies and methods of translating such form of nominative language games as neological quasi-terms.

\section{Methods}

\subsection{Algorithmic modeling of the translator's strategies}

We understand quasi-terms as nominations coined within a popular scientific discourse to designate new objects in the fields of science and/or technology though aimed not as much at conveying denotative information about their referents as attracting public attention to them. Thus, the use of quasi-terms induces in their contexts what Kharkiv linguist Vladyslav Hoverdovskii aptly labeled as "terminological connotation" [6, p.170] that, in its turn, provides these contexts with "a peculiar terminological coloring - as an imprint of a 
typical for a term technical or scientific context" [7, p.158]. In our opinion, terminological connotation induced by quasi-terms can be considered as a manifestation of language games of its own that should be separated from a nominative one and studied correspondingly. The meaning of a language game in this case is determined by the author's violation of a stylistic neutrality of narration and mixing the unit's scientific contents with its expressive form.

Translation-wise, the quasi-terms are of particular interest as they are lexical innovations not registered in the lexical systems of both source and target languages and thus represent a special variety of translation difficulties. We accept the definition of translation difficulties formulated by one of the co-authors of this research: "Translation difficulties are linguistic/discourse formations of different levels that set up barriers on the way of interlinguistic - verbal and non-verbal - communication as a result of objective differences in the structures and functioning of source and target languages as well as of subjective perception of these differences by the translator who is expected to exert considerable creative effort for their elimination" [8, p.106]. Following this definition, we conclude that the potential difficulties of translating neological quasi-terms lie in the necessity: (1) to formulate their meanings that at this stage are of a shifting rather than fixed character; and (2) to choose forms for rendering these meanings in the target contexts. Taken together, these factors condition quasi-terms' translation as a problem whose resolution requires a strategic approach.

According to Michael Cronin, the notion of a strategy serves as a link between translation and games, though traditional for Translation Studies culturally-oriented understanding of strategies (ranging from Schleiermacher to Venuti) "needs to be redefined somewhat in translation theory in order to cater for two levels of strategic analysis - the level of translator as reader and the level of translator as writer" [9, p.92]. The kind of reconsideration suggested by Cronin can be achieved due to the psycholinguistic view of a translation strategy. Psycholinguistic potential of translation strategies is determined by the attempts to embed them in a model of speech production. To this end, the concept of communicative strategies can be successfully utilized taking into account that obvious fact that translation is a form of (interlinguistic and intercultural) communication.

Psycholinguistic perspective of communication strategies is outlined by Nanda Poulisse in the following way: "The speaker who has planned his message needs to encode this at a certain stage. To do this he has to retrieve the appropriate words from his mental lexicon. If he is able to do this, language use is nonstrategic. If, however, his lexicon does not contain (one of) the required words, he needs to adopt a communication strategy" [10, p.160]. We believe that this approach can be fruitfully exploited in the field of Translation Studies accentuating three aspects of the translator's behavior that are of special importance for our research: strategy is seen as (1) a potentially conscious (2) mental plan for (3) problemsolving.

Consequently, the idea of the translator's psycholinguistic strategy allows to represent the process of translation as "a string of logically interconnected actions aimed at resolving a certain task or group of tasks" [11, p.62]. The naturalness of algorithmic modeling of translation process is stipulated by its closeness to the real process of forming the translator's strategy and taking separate decisions within its scope. In our case, the algorithm of translating quasi-terms as a two-stage process is offered. Each stage, in its turn, can be described as a separate strategy providing for a number of operations.

At the first stage, the absence of a quasi-term in the translator's mental lexicon as well as in the dictionaries of a source language makes him/her conduct neologism's semantic interpretation for which purpose several prospective methods can be laid out, such as morphemic (composition) analysis or contextual analysis. At the same time, the fact that word-formation is based on the analogy rather than rules and models makes us assume that 
construing the neologism's meaning by a recipient (translator, in our case) is mirroring its formation by the author. If so, the list of prospective methods of quasi-terms' interpretation should be supplemented with the analysis by analogy. Though the application of each of the above methods can also be split in a sequence of operations, we are not planning to do it here since these operations themselves have no relation to the notion of translation strategy per se.

At the second stage - that of reconstruction - the translator faces a number of options, such as: (1) to coin a new unit (equivalent) by him/herself by the means of a target language; (2) to find in the lexical system of a target language a unit close in its meaning to that construed at the first stage and to apply it as an equivalent; (3) to express the meaning construed at the first stage descriptively (method known as 'descriptive translation'); or finally (4) to exclude the unit in question from the target (con)text (method known as 'omission').

\subsection{Retrospective experiment for researching the translator's strategies}

In order to verify algorithmically modeled strategies we designed and conducted a retrospective experiment proceeding from Daniel Gile's methodology known as 'Integrated Problem and Decision Reporting', or IPDR. Elaborated as early as 1979, it was initially employed as a didactic tool that provided the teacher with an opportunity to evaluate the students' progress and the students - to carry out their translations in a more conscious way. Later on, the methodology was adapted for research needs: "In its didactic version, IPDR proceeds in three phases, the reporting phase, the data analysis phase, and the instructor's response phase. In a research version, the third phase can be replaced or complemented with different or follow-up phases, for instance, with further questioning of students on specific problems, action, decisions or other phenomena" [12, p.20].

Trying to adapt Gile's methodology to the purpose and conditions of our experiment, we made some amendments to it. Firstly, we tasked the subjects to report not all potential problems encountered in the course of translation, but to comment on the following issues: "Please, translate the sentences in the task paying attention to neologisms in bold that have no regular equivalents in Ukrainian. Then, under each sentence describe what methods you employed to interpret (to construe the meaning) of these neologisms. Then describe your strategy of reproducing these neologisms in Ukrainian." Secondly, the subjects were asked to send their translations and reports to the experiment's supervisors who analyzed them and generalized obtained data for further research. As one can see, the main differences between our methodology and Gile's one lie in (1) the absence of the third - didactic stage that seems irrelevant to the aim and tasks of our experiment and in (2) the concentration of the subjects on specific problems rather than translation in general.

The choice in favor of the retrospective experiment was preconditioned by the claim that it "gives greater insight if one wishes to study the translator's global strategies or the cross-cultural aspects of translation" [13, p.17], because "in retrospective verbal reports the translators will express the awareness of the function of the translation, of the recipients and of own strategies, in a more global way than in concurrent thinking aloud" [ibid., p.7].

Another apparent advantage of retrospection is that it allows to obtain information that corresponds exactly to the aim and tasks of the research by channeling the subjects' attention in the necessary direction by means of carefully formulated questions: "... translator interviews can provide better-quality data because they enable the researcher to put the same set of specially focused questions to a number of subjects, instead of allowing the translator to ramble at will" [14, p.61]. 
The participants of the experiment were 34 students of V.N. Karazin Kharkiv National University (Ukraine) that study for the Master's Degree in "English Language, Literature and Translation". As students, they already possess considerable amount of theoretical knowledge as well as a high level of linguistic competence though they obviously lack for the translator's experience. Thus, students of this level fall under the category of 'semiprofessional subjects' who, according to some observations, take decisions in a more conscious manner. At the same time their professional competence is not fully formed, i.e. they have not developed standard ways of coping with different kinds of problems [15].

The material of the research was twofold. Firstly, it is the abstracts from popular scientific journals that contain quasi-terms together with their Ukrainian translations made by the experiment's subjects. Secondly, it is the subjects' commentaries in the form of retrospective reports. All in all, the experiment involved six abstracts with ten quasi-terms. This publication is dealing with the analysis of the first three quasi-terms located within one abstract. The rest of the control units will be analyzed by one of the co-authors as part of her PhD project.

\section{Research results}

Let us begin with considering the specifics of semantic interpretation and construing the meanings of the three control units by the experiment's subjects. The quasi-terms under consideration are located within the following context:

Robotics is hardly the only emergent industry that can expect the embrace of the techno-enthusiast. Maybe bioinformatics and the diffusion of genetic engineering technologies and techniques will inspire a new generation of bio-hackers. Certainly the technologies are there for those inclined to genetically edit their plants or pets. Perhaps this decade will bring a Bill Gates of bio-hackerdom - an entrepreneur who can simultaneously innovate and market his or her DNA-driven ideas (MIT Technology Review).

The first two neologisms 'techno-enthusiast' and 'bio-hacker' are coined with the help of semi-prefixes 'techno-' and 'bio-' that have long gained popularity in the English terminological and quasi-terminological word-formation. Their meanings are well established as well: "bio - word-forming element, especially in scientific compounds, meaning 'life, life and', or 'biology, biology and', or 'biological, of or pertaining to living organisms or their constituents', from Greek 'bios' - 'one's life, course or way of living, lifetime"” [16] and "techno - word-forming element meaning 'art, craft, skill', later 'technical, technology,' from Latinized form of Greek 'tekhno' - 'art, skill, craft in work; method, system, an art, a system or method of making or doing"' [ibid.]. They also have established Ukrainian equivalents 'біо-' and 'техно-' that have been represented in a considerable number of Ukrainian terminological and quasi-terminological coinages. Suffix '-dom' engaged in the formation of the third control unit ('bio-hacker' + '-dom' = 'biohackerdom') is of a more abstract (generalized) meaning, and this fact can have a potentially negative impact on the subjects' ability to successfully construe the overall meaning of the quasi-term: “-dom - abstract suffix of state, from Old English 'dom' 'judgment, statute"” [ibid.].

The successfulness of the interpretation stage provides for the eligibility of the rest of the translators' decisions. In terms of the metaphor of game, one can state that the translator who did not manage to construe sufficiently coherent meaning of the source unit or ascribed it an erroneous meaning loses to the author already in the first period.

The interpretation of the quasi-term 'techno-enthusiast' turned out successful for $100 \%$ of the experiment's subjects. The most popular method of the analysis in this case was that 
of morphemic composition. See, for instance, Report \# $3^{\dagger}$ : "Morphemic analysis was applied for interpreting, because separate parts of the control word are already assimilated in the Ukrainian language: 'техно-' is used in compounds to indicate their connection to technology, and 'enthusiast' is a common usage word as well"; Report \#9: "The method of interpretation: morphemic analysis due to which one can see that the neologism 'technoenthusiast' was coined by combining regular word-building morphemes: prefix 'techno-' ('technology') and root noun 'enthusiast'."

In some cases, the interpretation process was based on the meaning of a word-formation model. See, for instance, Report \#11: "For this example, we use semantic interpretation of the model 'someone who is enthusiastic about technology'. I see the word 'enthusiastic' as an amateur, a person who is fascinated with something"; Report \#7: "In the first case, we have nonce word 'techno-enthusiast'. This is a derivative with the main part 'enthusiast' and modifier 'techno'. The modifier is regular and fixated in the dictionary as 'relating to or involving technology'. The main component is also regular, thus we can combine them and interpret this nonce word as 'someone who is very interested in and involved with technologies', that is, to use the interpretation of a word-formation model."

Another powerful source of information about the analyzed quasi-term was the vocabulary definitions of its components which provided the basis for construing the unit's overall meaning. See, for instance, Report \#4: "The word 'techno-enthusiast' consists of two components: the main part 'enthusiast' ('a person who is very interested in a particular subject or activity') and prefix 'techno-'. The source word thus means 'a person who is interested in technological novelties or products on a non-professional level'"; Report \#16: "In English, this word consists of the main part 'enthusiast' and prefix of the Greek origin 'techno-'. The word 'enthusiast' means 'a person who tends to become ardently absorbed in an interest'. Prefix 'techno-' relates to or involves technology. By putting these two elements together, we get 'a person who is interested in technological novelties or products on a non-professional level, just because of enthusiasm of learning it'."

At least two subjects mentioned the analogy as the main mechanism of interpreting the quasi-term. See, for instance, Report \#20: 'Neologism 'techno-enthusiast' can be translated by analogy with the word 'car enthusiast' that is translated as 'автолюбитель",; Report \#26: "While translating the first word 'techno-enthusiast', I opted for the strategy of similarity. First of all, I decided to see if there are any similar words in English. I looked up the meaning of the word 'car-enthusiast' and made my own translation by analogy."

In case of the quasi-term 'bio-hacker', successful interpretation of the meaning was conducted by 33 out of 34 subjects (97\%). Report \#19 provides erroneous interpretation the logic of which remains unclear: "First of all, we turn to the explanation of the meaning of 'bio-hacking"' in PBS News Hour: 'The whole idea of biohacking is that people feel entitled, they feel the ability to just follow their curiosity - where it should go - and really get to the bottom of something they want to understand'. In the Ukrainian language this meaning corresponds to the word 'самоучка'. But proceeding from this explanation we should add clarification 'винахідник'. Correspondingly, 'bio-hackers' are 'винахідникисамоучки'."

Like in the previous example, the quasi-term coined according to the model Pref $+\mathrm{N} \rightarrow$ $\mathrm{N}$ is quite expectedly interpreted by the subjects on the basis of the same methods and/or mechanisms. In particular, morphemic composition is mentioned. See, for instance, Report \#3: “... morphemic analysis was helpful, but I also had to turn to the context because I could not immediately understand what 'bio-' stood for in this word. From the context, I

\footnotetext{
$\dagger$ The original reports are in Ukrainian but for the convenience we translated the cited fragments into English.
} 
made the conclusion that it [the word] is somehow related to genetic research. Thus, similarly to 'techno-', 'bio-' is also used to form compounds in the sphere of biology."

Morphemic analysis can be mixed with contextual one for finding the most optimal variant of the neologism's meaning. See, for instance, Report \#7: "In this case, it is hard to make a correct interpretation on the basis of morphemic composition alone, thus we add context '....inclined to genetically edit...' and receive 'someone who genetically breaks his or her or other living organism in order to improve it"”; Report \#14: "I interpreted the word contextually and found out that it was about genetic modification of animals and plants."

We also encountered indications at the use of vocabulary definitions of the morphemes involved in coining the quasi-term. See, for instance, Report \#14: "The main element of 'biohacker' is the term 'hacker' that means 'a person who is skilled in the use of computer systems', but in our case, after combining it with 'bio-' that means 'something related to life' we receive a new meaning 'a person who performs science experiments on yeast or other biological organisms'."

Information about the specifics of English word-formation and meanings of wordformation models and/or affixes turned out quite useful for some subjects. See, for instance, Report \#11: 'In this case, model V + er $\rightarrow \mathrm{N}$ ('hack' + 'er' $\rightarrow$ 'hacker') is used; we consider this word together with prefix 'bio-' and receive literally 'біохакери'”; Report \#9: "Morphemic analysis also helps interpret the neologism 'bio-hackers' that contains the indication of the doer of an action '-er'."

Finally, the interpretation of the quasi-term 'bio-hackerdom' turns our most difficult and least successful, which is proved by seven erroneous interpretations $(20 \%)$. Though, on the one hand, this control unit is derived from the previously analyzed one (which is expected to foster interpreting), on the other hand, the suffix employed for word-formation is of an abstract character and is not very productive (which is expected to hinder interpreting). Among erroneous interpretations, the most typical one is determined by referring the quasi-term to the lexico-semantic category 'person' instead of 'abstract entity' that can be explained, firstly, by the absence of information as to the meaning of '-dom' in the subject's mental lexicon and, secondly, by contextual location of the quasi-term between proper name 'Bill Gates' and professional nomination 'entrepreneur'. See, for instance, Report \#32: “Bio-hackerdom', it is not clear, what it is. Is it a place or is it a person? But since we have Bill Gates on its right, we will assume that it is 'підприємець'. Moreover, it is later explained what kind of actions this person will fulfil"; Report \#23: "'Bio-hackerdom' is a neologism that was created with the help of suffix '-dom' and it means a person that is engaged in studying DNA as an amateur."

Relevant interpretations of the third quasi-term are mostly obtained due to the application of morphemic analysis. See, for instance, Report \#30: "Now about the word 'hackerdom'. Morphemic analysis shows that the word consists of two parts: 'hacker' + 'dom'. The first constituent was translated earlier, thus we will simply use the equivalent proposed earlier. The second is English suffix that is used to denote the nouns with the meaning of a field or sphere. Put together, these constituents make a lexeme meaning 'the realm or sphere of computer hackers'."

Another important method of ascribing meaning to the third quasi-term is by the vocabulary definitions of the morphemes within it. See, for instance, Report \#7: "Let us conduct the analysis: 'hacker' is a root morpheme, '-dom' is a suffix that has a meaning 'domain (kingdom), collection of persons ('officialdom'), rank or station ('earldom'), or general condition ('freedom')'. After additional contextual analysis, the nonce formation can be interpreted as 'sphere of hackers' or 'collection of hackers', or to be more precise as 'sphere of bio-hackers' or 'collection of bio-hackers'."

Let us switch to the next task of the experiment - the description of the strategies for reproducing the quasi-terms in English-Ukrainian translations as well as the linguistic 
means of these strategies' implementation. The first control unit 'techno-enthusiast' was reproduced by all the subjects, and vast majority of them employed the method of loan translation, i.e. used direct equivalents of the source morphemes. By doing this, they accepted the rules of the nomination game offered by the author. Closest to the original is the variant 'техно-ентузіаст'/“техноентузіаст' (14 or 41\%) that reproduces both meaning and form of the source unit not violating target linguistic norms. See, for instance, Report \#28: "After splitting the neologisms into separate components, I found Ukrainian equivalents to them and applied the method of loan translation. In the English original, the neologisms were formed by uniting two morphemes that have their regular equivalents in our language." The second popular translation variant was the one in which the root morpheme of a foreign origin was substituted with the Ukrainian equivalent 'любитель', 'прихильник' or 'шанувальник' ('технолюбитель', 'технолюб', 'техно-шанувальник'). See, for instance, Report \#7: "I use for translation autochthonous Ukrainian equivalent + loan translation. We can opt between two variants: 'ентузіаст' and 'любитель'. I preferred 'любитель' because for 'ентузіаст' there is no meaning 'той, хто займається улюбленою справою' (and is not just a proponent) like it is implied by the context"; Report \#26: "I found in the dictionary the meaning of the word 'car-enthusiast' that is translated into Ukrainian as 'автолюбитель'. Following this analogy, I translated 'techno-enthusiast' as 'техно-шанувальник'. I believe that this word could have also been translated as 'техноентузіаст' or as 'палкий шанувальник техніки'.”

In some other cases, the translators resorted to noun-phrases ('любитель техніки', 'любитель технологій', 'прихильник технологій'), which, taking into account the specifics of Ukrainian word-formation, cannot be referred to descriptive translations. See, for instance, Report \#9: "Translation strategy: I render the English neologism with the help of loan translation and add [the transformation of] permutation since noun 'enthusiast' has an autochtonous Ukrainian equivalent 'любитель' and prefix 'techno-' can be transformed into noun 'техніка' to make the final variant closer to regular units like 'любитель машин' or 'любитель музики'.”

Among the variants of reproducing English 'techno-enthusiast', there are several equivalents with a colloquial connotation ('техно-фанатик', 'технофан', 'техноман', 'технар') that, in our opinion, do not quite fit into the popular scientific style of narration and thus reduce the level of communicative equivalence. Though, the subjects that offered them did not see it as a problem, but rather as an advantage. See, for instance, Report \#4: "In order to adapt the unit to the target language we turned to adaptive transcoding and preserved prefix 'техно-'; instead, we substituted 'enthusiast' with an equivalent whose meaning is somewhat hyperbolized - 'фанатики'. As a result, the information contained in the source word ('those interested in technological advances') was preserved in the coinage 'техно-фанатики", Report \#8: "For the part 'enthusiast', I opted for the strategy of contextual substitution; in my opinion, the use of 'ентузіаст' does not suit this context. The word 'фан' from 'фанат' is more usable and modern though it has some slang overtones."

Three subjects offered a descriptive translation of the quasi-term that cannot be regarded as the translator's complete defeat since descriptive translation allows to render the source meaning ('той, хто працює 3 технологіями', 'ентузіаст, зацікавлений у новітніх технологіях'), but at the same time it is not a complete victory since quasi-terminological form is lost together with terminological connotation mentioned earlier. Unfortunately, the subjects' reports do not allow to fully comprehend their motivation. See, for instance, Report \#12: "For translating 'techno-enthusiast' I employed descriptive method. Proceeding from the context, I realized that it was about new technologies in the field of genetic engineering”; Report \#21: “The dictionaries translate 'techno' as 'техно' derived from 'технічний'; 'enthusiast' as 'любитель', that is why it makes sense to explain this neologism as 'людина, яка працює у технологічній галузі'.” 
The second control unit 'bio-hacker' was reproduced by all the subjects in its nominative form of a quasi-term and vast majority of participants (32 or 94\%) offered equivalent 'біохакер'“біо-хакер' that is maximally close to the source unit both structurally and semantically. We believe that this fact should be regarded as an indicator of the translators' victory. Their considerations as to the selected strategy and/or the method of translation are formulated in a rather typified manner - as a logical consequence of morphemic analysis. See, for instance, Report \#2: “There is term 'хакер' in the Ukrainian language; prefix 'бio-' is understood intuitively; that is why I decided to apply loan translation"; Report \#14: "For rendering, we used loan translation combined with transcoding (transliteration)"; Report \#22: "There is word 'хакер' in Ukrainian that is why I use loan translation and receive 'біохакер"”; Report \#34: "In regard to 'bio-hackers', I also employed loan translation because the word 'хакер' exists in Ukrainian and its meaning is comprehensible for an average recipient, thus I assume that the meaning of 'біохакери' which is additionally explained in the following context would be comprehensible as well."

Participant \#32 explained the use of concretization transformation by the following considerations: 'I took prefix 'bio-' out in favor of the adjective 'генетичний' because it can demonstrate the connection with DNA rather than life in general; I left 'hackers' intact, though now I am beginning to think that 'hackers' may bear a negative connotation and thus could be possibly substituted with 'генетичні програмісти' that would sound more neutral."

All the subjects attempted to reproduce the third control unit 'bio-hackerdom' though due to a large number of erroneous interpretations not all of them managed to do it successfully. Since causes and consequences of erroneous interpretations have been analyzed earlier in this research ('незалежний біо-хакер', 'біохакер', 'винахідниксамоучка', 'генетичний підприємець', ‘[той], який би займався питанням ДНК як любитель'), we would rather concentrate our efforts on those translation variants that are (more or less) related to the original and thus can be considered as the translator's victory. The first group among these equivalents is made by units received as a result of loan translation, that is units in whose composition we find Ukrainian analogues of English suffix '-dom'. In regard to Ukrainian stylistic and word-formation norms, variant 'біохакерство'/“біо-хакерство' seems most acceptable. See, for instance, Report \#4: "Suffix '-ство' is often used in Ukrainian to form generalized nouns. Thus, by searching for the Ukrainian equivalent, we turned to loan translation combined with transcoding ('бio-') and added suffix '-ство'. The information from the source unit was preserved in our 'біохакерство", Report \#17: “Biohackerdom' is a neologism coined by adding suffix 'dom' to the root morpheme. In Ukrainian, it corresponds to '-ство'. Loan translation + transcoding."

The second group is made by such (more or less) appropriate variants as 'біохакердом'/ 'біо-хакердом', 'хакеринг', 'біохакінг' whose authors did not take into account the factor of naturalness. Yet, creating the effect of unusualness was proclaimed as a leading translation strategy in Report \#16: "By selecting the Ukrainian equivalent, we turned to the method of loan translation, but we refused from suffix '-dom' in favor of the synonymous suffix '-ing' that is also used for making generalized nouns. This suffix is not peculiar to the Ukrainian language and thus represents the strategy of foreignization."

To some extent, such 'unnatural' variants of translation may testify to the absence of coherent conceptual representation of a source unit in the recipient's (translator's) mind. Obviously, this fact hinders the formation of a successful equivalent. See, for instance, Report \#26: “The word 'bio-hackerdom' was the hardest to translate in the whole text. Even after its morphemic analysis I could not make a definite conclusion as to what it meant, that is why I simply transliterated it as 'біохакердом'." 
The third group is made by the equivalents in which suffix '-dom' was abandoned in favor of nouns/noun phrases of similar meanings, such as 'рух біохакерів', 'біохакерська субкультура', 'спільнота біохакерів', 'царина біохакерства', 'сфера біотехнологій' As in case with 'techno-enthusiast', we are not incllined to treat such translations as descriptive. See, for instance, Report \#20: "Since it is rather hard to ascribe an exact meaning to the source unit, I decided to find some 'connections' in Ukrainian. As a result, we found a popular neologism to denote a new demographic group - 'хакерська субкультура'. Thus, we opted for the transformation of substitution"; Report \#20: "We translate 'bio-hackerdom' as 'царина біохакерства' because 'hackerdom' ('hacker' + 'dom') has exactly the same meaning."

\section{Discussion}

In this section, we would like to highlight such an important element of our research as substantiating the gaming nature of translation. Fully agreeing with referring translation to process-oriented language games by Wittgenstein [4], presenting the translator's decisionmaking as a formal game by Levý [17] and foregrounding the concept of a strategy as a major link between translation and games by Cronin [9], we would, nevertheless, like to add our own considerations concerning the notion of equivalence as a foundation for describing translation in its product-oriented dimension as a game. This intention seems logical for at least two important reasons: firstly, it conforms with the obvious fact that equivalence (regardless of its meaning that has varied from structural to semantic, functional, pragmatic, cultural and even cognitive) does not only determine the ontological status of translation but also stirs the course of Translation Studies development, and thus, any new attempt to see translation in a somewhat different light is doomed to failure without it; secondly, product-oriented approach to the game of translation in addition to process-oriented one (described, albeit partially, in the above sections) goes hand in hand with the dichotomous understanding of translation itself.

In our aspiration to apply (at least some of) the game theory provisions to the situation of translation, we need to understand in what cases the translator's decisions can be regarded as a victory over the author as a creator of a problematic situation (a winning translation strategy) and in what cases the translator's decisions lead to his/her defeat (a losing translation strategy)? The answer to this question is as simple as it is obvious. If the translation in its verbalized form corresponds to the translator's idea of equivalence (no matter, which) it falls under the category of victory, while insufficient level of equivalence or its complete absence brings the translation to the category of defeat. As our own research shows, there can be some intermediate cases, i.e. those that cannot be unequivocally treated as victorious or defeating. It is also important that the translator's idea of equivalence should correspond to the target cultural norms as well as the expectations of potential audience.

\section{Conclusions}

As a result of studying the translations and reports of the retrospective experiment's subjects, we obtained some indirect but valuable information as to resolving transaltion difficulties falling under the category of a nominative language game. Proceeding from the activity-based understanding of language games by Wittgenstein and Huizinga, we substantiated the translator's nomination as a variety of language games. To deepen our comprehension of the gaming nature of the translator's nominative actions we designed and conducted the two-stage retrospective experiment. In the course of the experiment, its semi- 
professional subjects interpreted and translated three quasi-terms of neological nature. The experiment confirmed the validity of algorithmically modeled psycholinguistic strategies of reproducing in the English-Ukrainian translation of quasi-terms as manifestations of language games and at the same time the variety of translation difficulties. The notion of a translation strategy in its psycholinguistic understanding is seen as a link between language games (e.g., nomination) and the game of translation. Thus, both the translator's decisionmaking and its results can be described in terms of a game metaphor. In particular, the fact that the majority of the experiment's subjects opted for the strategy of imitating the author's actions for the creation of source quasi-terms can be seen as their intention to play by the author's rules of the language game. Similarly, the strategy of reproducing control units on the basis of some other methods and/or means of word-formation is regarded as the translators' intention to offer their own set of rules for resolving problematic situations. In any case, the reproduction of the meaning close/identical to that of a source unit in a lexicalized form is treated as the translator's victory while the omission of a source unit in the target (con)text is a clear sign of defeat. Descriptive translation makes a separate situation as it cannot be treated as the translator's complete defeat (since the meaning is preserved) or complete victory (since the form is lost together with the terminological connotation).

\section{References}

1. E. N. Mishkurov, Moscow Univ. Bulletin. Language, language games and translation in modern lingustic, philosophical and cultural Understanding 1, 5 (2012)

2. M. V. Alekseeva, Typological specificities of scientific text: hypertextual typology of scientific language (Izd. Dom MISiS Publ., Moscow, 2015)

3. O. K. Kudasova The Role of stylystic tools in organizing scientific appreciation text (Yazyk i stil nauchnogo izlozheniia, Moscow, 1983)

4. L. Wittgenstein, Philosophical investigations (Basil Blackwell, Oxford, 1986)

5. J. Huizinga, Homo Ludens. A study of the play-element in culture (1980)

6. V. Y. Goverdovskyj, Knowledge and its variety in the text Connotation of terms, 170 (1987)

7. O. P. Mykhajlovych-Getto, Visnyk of Sumy State Univ. Connotation of quasi-term in advertising texts 1, 156 (2007)

8. O. V. Rebrii, Modern concepts of creativity in translation: a monograph (Kharkiv, 2012)

9. M. Cronin, Routledge encycl. of transl. st. Game theory and translation, 91 (2005)

10. N. Poulisse, The bilingual lexicon A theoretical account of lexical communication strategies, 157 (1993)

11. A. O. Ushakova, PNRPU Bulletin Algorythmic and heuristic mechanisms of thinking of a translator-linguist 1, 60 (2017)

12. D. Gile, The J. of Special. Transl. Integrated problem and decision reporting as a translator training tool 2, 2 (2004)

13. I. Rambæk, Romansk Forum Translation strategies expressed in retrospective and concurrent verbal reports 19, 7 (2004)

14. F. R. Jones, Transl. and Creativity Unlocking the black box: researching poetry translation processes, 59 (2007)

15. P. Kussmaul, S. Tirkkonen-Condit, TTR Think-aloud protocol analysis in translation studies 8(1), 177 (1995) 
16. Online Etymology Dictionary, https://www.etymonline.com

17. J. Levý The Transl.Studies Reader Translation as a Decision Process, 148 (2004) 